\title{
Evidence maze; het doolhof van het evaluatieonderzoek
}

Citation for published version (APA):

Nelen, H. (2008). Evidence maze; het doolhof van het evaluatieonderzoek. Maastricht University. https://doi.org/10.26481/spe.20080118hn

Document status and date:

Published: 18/01/2008

DOI:

10.26481/spe.20080118hn

Document Version:

Publisher's PDF, also known as Version of record

\section{Please check the document version of this publication:}

- A submitted manuscript is the version of the article upon submission and before peer-review. There can be important differences between the submitted version and the official published version of record.

People interested in the research are advised to contact the author for the final version of the publication, or visit the DOI to the publisher's website.

- The final author version and the galley proof are versions of the publication after peer review.

- The final published version features the final layout of the paper including the volume, issue and page numbers.

Link to publication

\footnotetext{
General rights rights.

- You may freely distribute the URL identifying the publication in the public portal. please follow below link for the End User Agreement:

www.umlib.nl/taverne-license

Take down policy

If you believe that this document breaches copyright please contact us at:

repository@maastrichtuniversity.nl

providing details and we will investigate your claim.
}

Copyright and moral rights for the publications made accessible in the public portal are retained by the authors and/or other copyright owners and it is a condition of accessing publications that users recognise and abide by the legal requirements associated with these

- Users may download and print one copy of any publication from the public portal for the purpose of private study or research.

- You may not further distribute the material or use it for any profit-making activity or commercial gain

If the publication is distributed under the terms of Article $25 \mathrm{fa}$ of the Dutch Copyright Act, indicated by the "Taverne" license above, 
Evidence maze; het doolhof van het evaluatieonderzoek 


\section{Colofon}

Ontwerp en print: Océ Business Services, Maastricht

ISBN: 978-90-5681-280-5

NUR: 820

Alle rechten voorbehouden. Niets uit deze uitgave mag worden verveelvoudigd, opgeslagen in een geautomatiseerd gegevensbestand of openbaar gemaakt worden, zonder voorafgaande schriftelijke toestemming van de auteur of uitgever. 


\section{Evidence maze; het doolhof van het evaluatieonderzoek}

Rede

in verkorte vorm uitgesproken bij de aanvaarding van het ambt van

hoogleraar Criminologie aan de Faculteit der Rechtsgeleerdheid van de Universiteit Maastricht

op vrijdag 18 januari 2008

door

Prof. dr.mr. J.M. Nelen

\section{Maastricht University}




\section{Evidence maze; het doolhof van het evaluatieonderzoek}

Mijnheer de rector magnificus, waarde collega's, studenten, lieve familie, vrienden en vriendinnen, dames en heren,

Vier maanden geleden, op 20 september 2007 om precies te zijn, sloot Charles Ludovicus Geerts, beter bekend als 'Dikke Charles', een voorlopig verkoopcontract met NV Stadsgoed, een dochteronderneming van woningcorporatie Het Oosten waarin de gemeente Amsterdam een meerderheidsbelang heeft. De transactie - waarmee een bedrag was gemoeid van 25 miljoen euro ${ }^{1}$ - had betrekking op achttien prostitutiepanden van Geerts in het fameuze Wallengebied. De levering van de panden vond nog geen twee weken geleden plaats. ${ }^{2}$

Charles Geerts, een voormalige marktkoopman in groenten en fruit, maakte zijn fortuin met de oprichting van een postorderbedrijf in erotische artikelen. Hij breidde zijn imperium in de seksindustrie gestaag uit en werkte zich in deze sector, en in het Wallengebied in het bijzonder, op tot één van de toonaangevende ondernemers. Geerts is menigmaal in verband gebracht met georganiseerde criminaliteit. Hoewel hijzelf nooit doekjes heeft gewonden om zijn vriendschappelijke relaties met een aantal personen uit het criminele milieu - van wie wijlen Klaas Bruinsma, alias 'De Lange' of ‘De Dominee'3 ontegenzeggelijk de bekendste was - is, afgezien van een fiscaal delict, zijn betrokkenheid bij criminele activiteiten in strafrechtelijke zin nooit aangetoond. Hij is althans nooit strafrechtelijk veroordeeld voor de diverse ernstige delicten - variërend van de verspreiding van kinderporno, witwassen, tot deelname aan een criminele organisatie - waarmee hij in de loop der jaren is geassocieerd. 4

Geerts heeft gedurende de afgelopen decennia niet alleen in de belangstelling gestaan van politie en justitie, maar wist ook jarenlang de schijnwerpers van het bestuur op zich gericht. In het kader van de

\footnotetext{
De Volkskrant, 21 september 2007.

2 In afwachting van een definitieve bestemming zijn de panden voorlopig in gebruik als ateliers voor mode-onderwerpers.

3 Om kleurrijke bijnamen hebben ze in het criminele milieu nooit verlegen gezeten.

4 Geerts is lange tijd gerekend tot de 'erven Bruinsma'. Na de liquidatie van Klaas Bruinsma voor het Hilton Hotel op 27 juni 1991 zouden drie personen, onder wie Geerts, de regie over de criminele activiteiten van Bruinsma hebben overgenomen. De 'IRT-affaire', die later nog zou leiden tot de Enquête Opsporingsmethoden (de Commissie-Van Traa), had betrekking op het onderzoek naar deze zogenaamde Delta-organisatie.
} 
bestuurlijke aanpak van georganiseerde criminaliteit bracht de gemeente Amsterdam op donderdag 30 november 2006 zwaar geschut tegen Geerts in stelling: op basis van een advies op grond van de Wet Bevordering Integriteitbeoordelingen door het Openbaar Bestuur (BIBOB), werden alle vergunningen van Geerts door het bestuur ingetrokken. Dit nadat het landelijk Bureau BIBOB een negatief advies aan de gemeente Amsterdam had gegeven, inhoudende dat serieus rekening moest worden gehouden met de mogelijkheid dat de vergunningen zouden worden misbruikt voor het plegen van delicten. Het feit dat Geerts ook als informele bank van lening fungeerde voor collega-exploitanten van bordelen, die langs reguliere weg geen financiering konden bewerkstelligen, heeft bij dit advies ongetwijfeld een rol gespeeld. Speculaties als zou de ondernemer op deze manier grote hoeveelheden crimineel geld hebben witgewassen, waren althans niet van de lucht. Geerts was een bezwaarschriftprocedure gestart tegen de beschikking om zijn vergunningen in te trekken, maar de koopovereenkomst duidt er op dat zowel de ondernemer als de gemeente eieren voor hun geld hebben gekozen, vermoedelijk om een langdurige, en voor beide partijen met onzekerheden omgeven bestuursrechtelijke procedure te voorkomen.

De casus-Geerts heeft noch in de media, noch in de wetenschappelijke literatuur tot dusverre geleid tot verhitte discussies, maar wanneer dat wel gebeurt is redelijk voorspelbaar uit welke hoeken de wind zoal zal waaien. Critici zullen vooral geneigd zijn om het kolossale bedrag ter discussie te stellen dat van overheidswege is neergelegd om iemand uit te kopen wiens vergunningen kort tevoren waren ingetrokken. Sterker nog, zij zullen betogen dat, als er al illegaal verkregen vermogen in de prostitutiepanden was geïnvesteerd, de overheid met de aankoop van de panden een handje heeft geholpen om dat vermogen wit te wassen. Daarnaast zal ongetwijfeld gerefereerd worden aan mogelijke verplaatsingseffecten. Niet duidelijk is immers wat de betrokkene met het vermogen dat hij aan de verkoop van de panden heeft overgehouden, gaat doen. Ook zal worden opgeworpen dat niet uitgesloten moet worden geacht dat Geerts, ondanks een passage in de koopovereenkomst dat hij geen activiteiten meer in de rosse buurt mag ontplooien, op de achtergrond, via een netwerk van rechtspersonen en strolieden, de regie over een deel van de prostitutiesector zal blijven voeren.

Deze sceptische geluiden zullen vermoedelijk worden overstemd door het enthousiasme waarmee het vermeende succes van de bestuurlijke aanpak van georganiseerde criminaliteit heden ten dage wordt uitgedragen. Menig bestuurder, ambtenaar en opsporingsfunctionaris zullen het aan- 
gekondigde vertrek van Geerts uit de rosse buurt aangrijpen om te onderstrepen dat de overheid wel degelijk in staat is om dammen op te werpen tegen criminele innesteling in bepaalde buurten of sectoren. Zij zullen de casus opvoeren als een schoolvoorbeeld van een waakzame overheid die paal en perk stelt aan het faciliteren van criminele activiteiten. In één adem met het vertrek van Geerts zal de voorgenomen sluiting van misschien wel het bekendse luxebordeel van Nederland, Yab Yum, worden genoemd. Ook bij deze gelegenheid heeft de gemeente Amsterdam de verlenging van de exploitatievergunning aangegrepen om een drempel op te werpen en ook in dit geval ligt aan de bestuurlijke ingreep een negatief advies van het Bureau Bibob ten grondslag. ${ }^{5}$ Last but not least zal worden gewezen op het door de rijksoverheid en de gemeente Amsterdam in juli 2007 geëntameerde project Emergo. In dit project wordt momenteel onder leiding van een aantal collega-criminologen een diepgravende analyse uitgevoerd van de verweving van illegale en legale activiteiten in het Wallengebied. Het is de bedoeling dat de resultaten van deze criminaliteitsanalyse door de verschillende handhavinginstanties die zich aan dit project hebben gecommitteerd worden benut om de criminele machtsconcentraties en achterliggende gelegenheidsstructuren in het Wallengebied ${ }^{6}$ (en een deel van het Damrak) te bestrijden en in de toekomst te voorkomen. ${ }^{7}$

De justitiële en bestuurlijke maatregelen staan niet op zichzelf maar gaan gepaard met een grootschalige vorm van stadsvernieuwing. Precies een maand geleden presenteerden burgemeester Cohen en wethouder Asscher het 'Coalitieproject 1012', vernoemd naar het postcodegebied in

5 De voorgenomen sluiting houdt verband met het vermoeden dat de Hells Angels achter de schermen al jarenlang de economische controle over Yab Yum uitoefenen. De bestuursrechter oordeelde op 4 januari 2008 dat de BIBOB-rapportage de vermoedens voldoende aannemelijk maakt. Hoewel er nog een bezwaarschriftprocedure loopt, heeft het bordeel inmiddels haar deuren gesloten. (Volkskrant, 5 januari 2008). Hetzelfde lot dreigt voor Casa Rosso. De exploitant van dit 'sekstheater' kreeg gisteren - donderdag 17 januari 2008 - te horen dat intrekking van zijn vergunning op stapel staat.

6 Op 11 juli 2007 is het project Emergo officieel van start gegaan door middel van de ondertekening van een convenant door de ministers van Justitie en van BZK, de staatssecretaris van Financiën, de burgemeester van de gemeente Amsterdam, de hoofdofficier van Justitie van het parket Amsterdam, de korpschef van de regiopolitie Amsterdam/Amstelland en de voorzitter van het dagelijks bestuur van het stadsdeel Amsterdam-Centrum.

7 Deze passage is afkomstig uit het "Programma versterking aanpak georganiseerde criminaliteit", dat door het kabinet-Balkenende IV op 13 december 2007 naar de Tweede Kamer werd gestuurd. 
het centrum van Amsterdam. Dit project behelst een samenwerkingsverband tussen de gemeente Amsterdam en het stadsdeel Centrum aan de ene kant en tal van private partijen aan de andere kant - zoals gerenommeerde hotels, woningcorporaties, projectontwikkelaars, banken, beleggers en 'bonafide' ondernemers - en heeft tot doel om het oude stadshart een grondige metamorfose te laten ondergaan. Een groot aantal panden, waarin nu seksbedrijven, coffeeshops en andere kleine "louche" ondernemingen zijn gevestigd, zullen een andere bestemming krijgen. ${ }^{8}$

Het Coalitieproject 1012 en het Project Emergo moeten worden beschouwd als een intensivering van de aanpak die sinds 1997 in Amsterdam - aanvankelijk onder de naam Wallenproject, later omgedoopt in Van Traa-projectwordt gevolgd. Meer en meer wordt bij de bestrijding, preventie en indamming van georganiseerde criminaliteit gesproken over 'duale' strategieën, waarin parallel aan - en bij voorkeur geïntegreerd met - 'klassieke' strafrechtelijke bestrijdingsvormen bestuurlijke, fiscale en andere maatregelen worden getroffen. Deze aanpak wordt heden ten dage - in iets gewijzigde vorm - ook toegepast in de regio Zuid-Limburg onder de - overigens niet bijster originele - naam Operatie Schone Handen. ${ }^{9}$ Ook hier vullen verschillende benaderingswijzen en activiteiten elkaar aan. Net als in Amsterdam worden op basis van een criminaliteitsanalyse deelprojecten geselecteerd. In samenspraak met de vertegenwoordigers van de betrokken diensten en organisaties wordt vervolgens een plan van aanpak opgesteld en wordt vastgesteld wie de 'beste papieren' heeft om handelend op te treden. Het is de bedoeling dat de geïntegreerde aanpak ook in de rest van het land navolging krijgt. Op 12 september 2007 gaf minister Ter Horst van het ministerie van Binnenlandse Zaken en Koninkrijksrelaties daartoe het startschot. De minister ondersteunt de komende jaren regio's die een integrale bestuurlijke aanpak willen gaan toepassen via de oprichting van zes regionale expertisecentra. Gemeenten krijgen van deze centra specifieke ondersteuning bij bijvoorbeeld BIBOB-trajecten of het tegengaan van witwassen via vastgoed. ${ }^{10}$

Maar wat bepaalt nu precies de mate van effectiviteit van de hierboven genoemde duale strategieën? Vormen het aantal en de aard van de

8 Amsterdam heeft met behulp van NV Stadsgoed en woningcorporatie Het Oosten nu al 83 panden verworven in de rosse buurt.

9 Met deze naam werd het justitiële offensief tegen corruptie in Italië aan het begin van de jaren negentig van de vorige eeuw uitgerust, dat uiteindelijk de ondergang betekende van de destijds gevestigde politieke partijen in het land.

10 Uit: Programma versterking aanpak georganiseerde criminaliteit d.d. 13 december 2007. 
genomen bestuurlijke maatregelen - variërend van ingetrokken of geweigerde vergunningen, opgelegde dwangsommen, sluiting van bepaalde etablissementen tot de aankoop van panden - goede graadmeters voor de slagkracht van de overheid? Moeten naast deze maatregelen ook de opgelegde gevangenisstraffen, geldboetes, ontnemingsmaatregelen en fiscale naheffingen en boetes in de analyse worden betrokken? Zegt het feit dat sommige ondernemers op wie de geïntegreerde aanpak zich heeft gericht, de bedrijfsmatige activiteiten staken of de wijk nemen naar andere gebieden of sectoren iets over de effectiviteit van de aanpak? Zegt het opknappen - of revitaliseren, zoals dat tegenwoordig zo mooi heet - van buurten iets over de mate waarin de invloed van de georganiseerde criminaliteit in die wijken wordt teruggedrongen? In hoeverre leiden versterking van het overheidsoptreden en samenwerkingsverbanden met publieke en private partners eigenlijk überhaupt tot verzwakking van de georganiseerde criminaliteit?

Dit vragenlijstje is zeker niet uitputtend maar laat wel goed zien dat aan het begrip effectiviteit verschillende dimensies zitten. Ondanks de veelzijdigheid en complexiteit van het begrip wordt aan criminologen en andere sociaal-wetenschappers in toenemende mate de eendimensionale vraag voorgelegd of zij willen onderzoeken of de door de overheid gekozen strategie, werkwijze, of interventie 'werkt'. Deze roep om beleid dat evidence-based is, is niet alleen afkomstig uit beleidskringen of de politiek maar valt ook meer en meer te beluisteren in de eigen wetenschappelijke omgeving. Zo hield hoogleraar Methoden en Technieken van Criminologisch Onderzoek Catrien Bijleveld op 8 maart 2002 haar oratie aan de Vrije Universiteit Amsterdam onder de intrigerende titel "Mens, durf te meten!" Aan het einde van haar inaugurele rede stelde collega Bijleveld het gebrek aan wetenschappelijk gefundeerde kennis over straffen aan de kaak en wierp in dat verband de retorische vraag op "dat het toch niet zo kan zijn dat we slechtziend zijn en opzettelijk slechtziend blijven als het om de genezende werking van straffen gaat." Recentelijk sprak hoogleraar Forensische Psychologie Corine De Ruiter (2007) in haar inaugurele rede aan deze universiteit woorden van gelijke strekking. Ook zij brak een lans voor het meten van de effecten van strafrechtelijke interventies, al was in de ogen van De Ruiter het gebrek aan effectiviteit van een aantal strafrechtelijke sancties al zonneklaar. Ik citeer: "Donner's beleid" tart alle wetenschappelijke evidentie over What Works om criminele recidive tegen

\footnotetext{
$"$ Gedoeld wordt op de reorganisaties die de vorige minister van Justitie, mr. P.H. Donner, onder
} de noemer 'Modernisering Gevangeniswezen' heeft doorgevoerd in het gevangeniswezen. 
te gaan. De nadruk op repressie, met opsluiting in de moderne varianten van kerkers, als basale overheidsstrategie om criminaliteit te beheersen is volledig achterhaald en in strijd met de wetenschappelijke kennis die de psychologie de laatste decennia heeft voortgebracht."

Zowel de beschouwing van Bijleveld als die van De Ruiter moeten gelezen worden als een pleidooi voor meer durf en creativiteit in criminologisch (en psychologisch) onderzoek, vooral met betrekking tot het meten van de effecten van interventies. Niemand zal die oproep betwisten of als onzinnig terzijde schuiven. Integendeel. Durf en creativiteit zijn immers de pijlers waarop gezonde wetenschapsbeoefening rust. Toch zit er een keerzijde aan de roep om meer evidence based science. Niet alleen wordt daarmee de schijn gewekt dat evaluatiestudies uitsluitend gecentreerd zijn rondom what works-vragen, maar ook dat door gebruik te maken van bepaalde onderzoeksdesigns alle relevante aspecten van criminaliteit en criminaliteitsbestrijding in eenduidige, cijfermatige eenheden zijn uit te drukken. Ook is betwistbaar of het realistisch en nastrevenswaardig is om bij elke beleidsmaatregel de vraag centraal te stellen of deze wel evidence-based is, ofwel voldoende leunt op wetenschappelijk bewijs. Ik leg mijn bedenkingen en bezwaren hieromtrent in het restant van deze rede graag aan u voor. Ik teken daarbij meteen aan dat mijn betoog geen methodologische beschouwing is. Waar ik het vooral over wil hebben is de bril die moet worden opgezet, willen we als criminologen tot zinnige en verantwoorde uitspraken komen over de werking en de gevolgen van interventies op gebied van de rechtshandhaving. Ik spits mijn betoog over evaluatie toe op de hierboven kort toegelichte geïntegreerde aanpak van georganiseerde criminaliteit.

De geïntegreerde aanpak herbergt een repressief maar ook een belangrijk preventief element in zich. In lijn met de centrale gedachte die schuil gaat achter risicojustitie $e^{12}$ ligt aan deze aanpak de premisse ten grondslag dat omstandigheden en gelegenheden die malafide praktijken in de hand kunnen werken inzichtelijk moeten worden gemaakt. Vervolgens moeten maatregelen worden genomen om de in kaart gebrachte risico's te verkleinen. In de criminologie wordt een dergelijke benadering veelal aangeduid

12 Met de term risicojustitie wordt gedoeld op de ontwikkeling dat de bij de rechtshandhaving betrokken diensten zich bij hun optreden primair laten leiden door risicoverwachtigen en dreigingsanalyses. In de risicosamenleving wordt veel waarde gehecht aan preventief optreden teneinde allerhande veiligheidsrisico's te beheersen. Een risicosamenleving kiest in de woorden van Borgers (2007) noodgedwongen voor de vlucht naar voren teneinde 'het kwaad' in de kiem te smoren. 
met de term situationele criminaliteitspreventie.

Vooropgesteld zij dat het meten van de effecten van interventies die beogen veranderingen aan te brengen in risicovolle situationele omstandigheden iets wezenlijk anders is dan het meten van de effecten van interventies die zich richten op het bewerkstelligen van veranderingen onder veroordeelde delictplegers. ${ }^{13}$ Niettemin wordt ook rondom strategieën die geënt zijn op het principe van situationele criminaliteitspreventie de roep om evidence-based-policies steeds sterker.

\section{Evidence-based}

De Angelsaksische term evidence-based is de afgelopen jaren in de Nederlandse wereld van wetenschappers, beleidsmakers en politici behoorlijk ingeburgerd geraakt. De gedachte dat beleidsinterventies geschraagd worden door wetenschappelijke inzichten heeft op justitieel terrein dusdanig om zich heen gegrepen, dat het hedendaagse debat over bijvoorbeeld de effectiviteit van penitentiaire programma's, tbs-behandelingen etc. volledig door dit paradigma lijkt te worden beheerst. Justitiële gedragsinterventies, gericht op het terugdringen van recidive, dienen bijvoorbeeld gebaseerd te zijn op een veranderingsmodel waarvan de effecten wetenschappelijk bewezen zijn. Is het laatste niet het geval, dan wordt de interventie rücksichtslos overboord gezet. Maatgevend voor het bepalen van effectiviteit van een interventie is de vraag hoe de interventie scoort op de meetlat, zoals ontworpen door de Campbell Collaboration. ${ }^{14}$

13 Bij gedragsinterventies gaat het om een methodische handeling op microniveau, gericht op het beïnvloeden van iemands gedrag of individuele omstandigheden, met als doel de verminering van recidive. Bij het meten van de effecten van gedragsinterventies is het gebruikelijk om onderzoeksdesigns te ontwerpen waarin een groep delictplegers die een bepaalde interventie heeft ondergaan qua recidive af te zetten tegen een vergelijkbare groep delictplegers die deze interventie niet heeft gehad. Bij interventies die leunen op het gedachtegoed van situationele criminaliteitspreventie is een dergelijk design niet bruikbaar. Zie in dit verband ook het artikel van Kleemans e.a. (2007) waarin uitvoerig wordt stilgestaan bij de verschillen tussen interventies die zijn toegespitst op individuen en interventies die zich richten op instituties of, soms zelfs, een volledige 'handhavingketen'.

14 Dit is een non-profit organisatie die als doel heeft om beleidsmakers te voorzien van informatie over de effecten van interventies op diverse terreinen (welzijn, onderwijs, criminaliteitsbestrijding etc). De resultaten van de systematische reviews die door de Campbell Collaboration worden uitgevoerd worden ook via de website van de organisatie toegankelijk gemaakt (www.campbellcollaboration.org). 
De eenzijdige oriëntatie op evidence based science conform de uitgangspunten van de Campbell Collaboration heeft mijns inziens geleid tot een verschraling van het evaluatieonderzoek. In sommige (wetenschappelijke) kringen bespeur ik de starre, dogmatische opvatting dat dit type onderzoek meer wetenschappelijke kennis zou genereren dan andere vormen van wetenschapsbeoefening. Fervente aanhangers van deze stroming zijn er bijvoorbeeld van overtuigd dat er ten aanzien van de evaluatie van interventiestrategieën een hiërarchie bestaat van high quality research, waarbij onderzoek dat zich bedient van randomized controlled trials aan de top van de ranglijst staat en het meer kwalitatief georiënteerde onderzoek onderaan bungelt. Pawson (2006) heeft de bezwaren tegen een dergelijke rigide kijk overzichtelijk op een rij gezet. Hij citeert in zijn boek ook Campbell zelf, die het belang van kwalitatief onderzoek altijd heeft benadrukt en wars is van een polemiek tussen aanhangers van verschillende onderzoeksmethoden. In de optiek van Campbell moet elke methode worden omhelsd die situatiespecifieke kennis genereert.

Ook Rovers (2007) plaatst kritische kanttekeningen bij de What worksbenadering. Eén van zijn kritiekpunten is dat in deze benadering de nadruk te sterk is komen te liggen op de standaardisering van producten en protocollering van werkwijzen. De sociale realiteit van de uitvoering van interventies en de betekenis die de subjecten die aan de interventie worden blootgesteld daaraan hechten, komt onvoldoende aan bod. ${ }^{15}$

Op de vraag vanuit welke perspectieven de grondslagen, uitvoering en effecten van criminaliteitsbestrijding en -preventie kunnen worden bestudeerd, kom ik in het vervolg van deze rede terug. Eerst sta ik even stil bij de nadruk die met het gebruik van de term evidence based policies wordt gelegd op de verwetenschappelijking van het beleid. Deze accentuering

15 Rovers (2007) signaleert in zijn boeiende lectorale rede behalve de twee reeds genoemde pijnpunten nog twee problemen met betrekking tot de what works -benadering. De nadruk op het gebruik van onderzoekssynthesen (met name meta-analyses) remt zijns inziens de toepassing van innovatieve interventiestrategieën. Daarnaast blijken de what works-beginselen onvoldoende houvast te bieden voor de interventiepraktijk. Ook Kleemans e.a. (2007) nemen afstand van een aantal premissen die aan de systematische reviews van de Campbell Collaboration ten grondslag liggen. Op basis van een analyse van 31 evaluatiestudies komen zij tot de conclusie dat strikt vasthouden aan de voorgeschreven methodologische criteria zou impliceren dat geen van deze 31 studies in een systematische review zou mogen worden meegenomen. Het gaat de auteurs te ver om al deze studies te diskwalificeren en als onbruikbaar terzijde te schuiven. Kleemans e.a. (2007) stellen een alternatieve werkwijze voor die op verschillende soorten van evaluatie kan worden toegepast. 
staat in zekere zin haaks op de veranderingen die hebben plaatsgevonden in de aard en toonzetting van het politieke debat. In de hedendaagse mediacratie worden politici bij het geven van een visie op een bepaald maatschappelijk probleem vaak meer gedreven door de uitkomsten van de meest recente opiniepeiling dan door de inzichten van wetenschappelijk onderzoek. Garland (2001) heeft in dat verband gewezen op de onmiskenbare opkomst van sound bites in de politieke cultuur. Krachtige no-nonsense uitspraken - vaak verpakt in ronkend taalgebruik - moeten het publiek er van overtuigen dat het de politici menens is. "Three strikes, you're out, "adult time for adult crime", "zero tolerance" of - om een recent Nederlands voorbeeld te noemen - "Verkoop het 'corrupte boevennest' dat de Nederlandse Antillen heet via Marktplaats.nl" - zijn maar enkele illustraties van politieke daadkracht waarin de nuance, laat staan de wetenschappelijke onderbouwing, ver te zoeken is. In de optiek van Garland (2001) past de verharding van het klimaat in een meer algemene tendens in de richting van een culture of control en zijn politici zich juist meer gaan verzetten tegen inperking van hun beslissingsmacht door de macht van wetenschappers en andere specialisten. Het is in dit verband goed om te wijzen op de paradox dat ongeveer gelijktijdig met de roep om evidence based policies de figuur van de spin doctor vaste voet aan de grond heeft gekregen in de politieke arena. En als er één aspect is waarin de laatste niet of nauwelijks is geïnteresseerd, is het de vraag of de uitlatingen van zijn of haar cliënt de wetenschappelijke toets der kritiek wel kunnen doorstaan. ${ }^{16}$ In het licht van bovenstaande ontwikkelingen is het niet verwonderlijk dat in het politieke debat het succes van een bepaalde aanpak al wordt geclaimd voordat er enige evaluatie heeft plaatsgevonden. Het is in dat verband ronduit fascinerend om te zien hoe politici over elkaar heen zijn gebuiteld om de stelselmatige afname in criminaliteit gedurende het afgelopen decennium politiek uit te buiten. Ik maak in dat verband een kort uitstapje naar de Verenigde Staten waar de daling in criminaliteitscijfers zich eerder manifesteerde dan in West-Europa.

Zowel politieregistraties als slachtofferenquêtes laten in de VS vanaf 1992 voor zowel vermogenscriminaliteit als geweldsmisdrijven een scherp dalende tendens zien. Zelfs met inachtneming van alle beperkingen die aan het gebruik van deze bronnen kleven, is de conclusie onontkoombaar

\footnotetext{
16 Van Dieren (2007) formuleert het nog scherper: "onwetenschappelijke ruis in de samenleving is voor politici een levensnoodzaak." Pawson (2006) werpt in relatie tot de spin doctor de niet van cynisme verstoken vraag op "hoe het ook weer zat met de bewijsvoering inzake de inval in Irak?"
} 
dat in de grote Amerikaanse steden een ongekende ontwikkeling heeft plaatsgevonden. In New York City - waar de afname zich het scherpst aftekende - daalden in tien jaar tijd de cijfers voor moord met $73 \%$, verkrachting met 52\%, gewapende overvallen met 70\%, mishandeling met $46 \%$, inbraken met $72 \%$ en autodiefstal met $78 \%$. Criminologen, die zich decennialang bekreund hadden om de almaar stijgende criminaliteitscijfers te verklaren, stonden aanvankelijk met de mond vol tanden over deze onverwachte trendbreuk. Politici, bestuurders en korpschefs waren er echter als de kippen bij om het succes van 'hun' aanpak te claimen. In hun optiek kon de daling aan niets anders worden toegeschreven dan aan de harde, robuuste aanpak van de onveiligheidsituatie in de binnensteden. Een aanzienlijke toename van 'blauw'op straat, gecombineerd met andere politiestrategieën ${ }^{17}$ en langduriger opsluiting van veroordeelden zouden goeddeels verantwoordelijk zijn geweest voor de spectaculaire criminaliteitsreductie. Tegen deze eendimensionale voorstelling van zaken is pas in een later stadium tegenwicht geboden. Zo hebben volgens de aanhangers van de gelegenheidsbenadering de diverse maatregelen die vanaf de jaren tachtig zijn genomen in het kader van situationele criminaliteitspreventie een decennium later de eerste vruchten afgeworpen. ${ }^{18}$ Weer anderen hebben de nadruk gelegd op de economische voorspoed die de Verenigde Staten in de jaren negentig kenmerkte. Ook is een relatie gelegd met de afname van de crackepidemie ${ }^{19}$ in de grote steden en met de beëindiging (vaak overigens op initiatief van de bendeleden zelf!) van een aantal gang wars. ${ }^{20}$ Tot slot hebben verschillende deskundigen gewezen op de demo-

${ }_{17}$ In dit verband wordt vooral gewezen op de (veronderstelde) toegevoegde waarde van community policing. Dit concept heeft als uitgangspunt dat de politie middenin de samenleving moet staan en dichterbij de burger moet opereren. "Kennen en gekend worden", is het leidende principe.

18 Eén van de geestelijke vaders van de rational choice benadering in de criminologie, Ronald Clarke, reageerde in zijn rede tijdens het laatste congres van de European Society of Criminology in Bologna (25-29 september 2007) enigszins verongelijkt toen de invloed van situationele criminaliteitspreventie op de daling van de criminaliteitscijfers aan bod kwam: "Security improvements are never mentioned in reports on crime drop. But is highly likely (although not proven) that they have significantly influenced crime rates."

19 Crack is de rookbare variant van cocaïne. De prevalentie van het crackgebruik daalde in de Amerikaanse steden gedurende de jaren negentig aanzienlijk en werd ook in verband gebracht met de scherpe daling van het aantal geweldsdelicten, in het bijzonder moord en doodslag. Zimring (2007) acht die correlatie aanvechtbaar.

20 Waarbij uiteraard de vraag kan worden opgeworpen in hoeverre de beslissing van bendeleiders om de vijandelijkheden te staken mede ingegeven was door overheidsbemoeienis. 
grafische veranderingen die de afgelopen decennia hebben plaatsgevonden. Als gevolg van een scherpe daling van de geboortecijfers is het aantal jongeren in de criminaliteitsgevoelige leeftijdscategorie 12-18 navenant afgenomen. De econometristen Donahue and Levitt (2001) leggen in dat verband zelfs een relatie met de legalisering van abortus in de Verenigde Staten aan het begin van de jaren zeventig. Volgens deze auteurs hebben vooral die vrouwen gekozen voor afbreking van de zwangerschap, die volgens de moderne inzichten voldoen aan een verhoogd risicoprofiel om kinderen op de wereld te zetten die later crimineel of anti-sociaal gedrag gaan vertonen - tienermoeders, alleenstaand, verslaafd, afkomstig uit 'zwakke' sociaal-economische milieus etc. -. Deze verklaring is vermoedelijk aan de born-right-christians in de VS, hoe ingenomen zij ook zijn met de dalende criminaliteitscijfers, niet besteed, maar dat terzijde. ${ }^{21}$

In een recentelijk verschenen boek heeft Zimring (2007) alle mogelijke verklaringen voor de criminaliteitsreductie op een rij gezet en tegen het licht gehouden. Hij concludeert - weinig verrassend - dat er niet één magic bullet te benoemen is, maar dat er sprake is geweest van een combinatie van factoren die op elkaar hebben ingewerkt en versterkt.

De bovenstaande beschouwing onderstreept nog maar eens dat wetenschappelijke en politieke rationaliteit vaak niet met elkaar sporen. Het is ook naïef om te veronderstellen dat de vraag naar wetenschappelijk onderzoek uitsluitend voortvloeit uit de behoefte om meer inzicht te verwerven in de werking van beleid of een specifieke interventie. Immers, op wetenschappelijk onderzoek wordt ook om tal van strategische redenen teruggegrepen. Zo is alleen al het in het vooruitzicht stellen van een evaluatieonderzoek vaak te beschouwen als een politiek gebaar, waarmee tijdwinst kan worden geboekt, weifelaars over de streep getrokken kunnen worden of waarmee kan worden nagegaan hoe een naar verwachting impopulaire maatregel het beste kan worden gepresenteerd om de maatschappelijke weerstand er tegen te minimaliseren (Nelen, 2000). Er wordt ook vaak door beleidsmakers en politici selectief gebruik gemaakt van onderzoeksbevindingen. ${ }^{22}$ Engbersen (2007) heeft daarvan recentelijk een

\footnotetext{
${ }^{21}$ Op de causale relatie die Donahue en Levitt (2001) hebben gelegd tussen abortus en dalende criminaliteitscijfers is overigens in wetenschappelijke kring kritiek geuit. Zo ontbreekt volgens Zimring (2007) de empirische grondslag voor de stelling dat vooral 'kansarme' vrouwen zich lieten aborteren. Het aantal kinderen dat in de jaren zeventig in risicovolle omstandigheden opgroeide nam volgens hem zelfs toe.

22 Het selectieve gebruik van onderzoeksresultaten heeft Majone (1989) zelfs verleid tot de volgende these: "evidence is cynically exploited in the interests of retaining rather than refining the exercise of power." Wetenschappelijk bewijs dus dat primair wordt aangewend ter consolidering van een machtspositie.
} 
mooi voorbeeld gegeven. Tijdens een parlementair debat over een onderzoek van zijn onderzoeksgroep over internationale migratie en illegaliteit wisten vijf politici van verschillende politieke partijen vijf uiteenlopende politieke interpretaties aan één en hetzelfde wetenschappelijke onderzoek te geven. ${ }^{23}$ En, last but not least, het leveren van evidence geschiedt hoe langer hoe meer in de context van derde geldstroomonderzoek. Universiteiten en andere wetenschappelijke instituten zijn in financiële zin steeds afhankelijker geraakt van externe opdrachtgevers. ${ }^{24}$ Over de vraag in hoeverre deze afhankelijkheidsrelatie een bedreiging vormt voor respectievelijk de academische vrijheid, de kwaliteit van onderzoek en de wetenschappelijke integriteit verschillen de deskundigen van mening. Zo achten Köbben en Tromp (1999) het risico van de aantasting van de wetenschappelijke integriteit groot. Zij lokaliseren het gevaar bij opdrachtgevers, die een groot belang hebben bij de uitkomst van onderzoek en daarom onderzoekers die met een onwelkome boodschap komen monddood maken of anderszins beïnvloeden - bijvoorbeeld door te laten doorschemeren dat men in de toekomst geen onderzoeksopdrachten meer hoeft te verwachten. Van de Bunt (2007) daarentegen ziet meer problemen bij de onderzoekers. De laatsten zouden te gemakkelijk meegaan in de denkwereld en de ambities van de opdrachtgever en beleidsmaker. Bijvoorbeeld door te korte doorlooptijden te accepteren bij het doen van evaluatieonderzoek. Het gevolg van een dergelijke - niet zelden omwille van politieke redenen ingegeven - korte onderzoekstermijn - is dat wetenschappelijke betrouwbare en valide conclusies over de werking van beleid of wetgeving niet mogelijk zijn. Eerder heb ik in het kader van wetsevaluaties daarover de retorische vraag gesteld of sociaal wetenschappers niet meer de rug moeten rechten en evaluatieopdrachten met een onredelijke evaluatietermijn eenvoudigweg moeten weigeren (Nelen, 2000). Ik maak me wat dat betreft overigens weinig illusies, want de al eerder aangestipte afhankelijkheidsrelatie als gevolg van het toenemend belang van derde geldstroomprojecten maakt dat ook op dit punt de marktwerking sterker is dan principes van wetenschappelijke zuiverheid en betrouwbaarheid.

\footnotetext{
23 In mijn proefschrift "Gelet op de Wet" komt een vergelijkbaar beeld naar voren over het selectieve gebruik door politici van de resultaten van de evaluatie van de ontnemingswetgeving (Nelen, 2000).

24 Pawson (2006) omschrijft de relatie tussen beleid en wetenschap zelfs als financieel circulair: "One arm of government is providing the funds for another to supply the evidence base."
} 


\section{Evidence-maze}

De bovenstaande overwegingen in beschouwing nemend zal het geen verbazing wekken dat ik de term evidence-based voor het hedendaagse criminaliteitsbeleid - of zo u wilt, veiligheidsbeleid - in meer dan één opzicht misplaatst vind. Daar komt nog iets bij. Termen als evidence-based of 'what works' - of het daar weer van af geleide 'best practices' - suggereren dat de kracht van wetenschap zou liggen in de bevestiging (in dit geval van de effectiviteit van een interventie). Het falsificatieprincipe van Popper indachtig komt de wetenschap echter nauwelijks vooruit wanneer uitsluitend gezocht wordt naar interventies waarvan op theoretische gronden verwacht kan worden dat ze werken. De vraag of 'iets werkt' zou voor wetenschappers ook veel minder interessant moeten zijn dan de vraag 'waarom iets zou kunnen werken, voor wie en onder welke omstandigheden'. Zoals ik hierboven met betrekking tot de scherpe daling van de criminaliteitscijfers in de Verenigde Staten al heb aangegeven, is het samenstellen van een top tien van meest succesvolle interventies een idéé fixe. Omdat de uitvoering van criminaliteitsbeleid plaatsvindt in een bepaalde maatschappelijke context, kan het zo zijn dat een interventie die in een bepaalde setting doorgaat voor 'best practice', onder andere situationele omstandigheden moet worden beschouwd als 'worst practice'. Ik moet er bijvoorbeeld niet aan denken dat de in Amsterdam en in deze regio ontwikkelde bestuurlijke aanpak van georganiseerde criminaliteit 25 morgen wordt ingevoerd in een van de nieuwe Europese lidstaten. Eén van de basispremissen van deze aanpak is namelijk dat de integriteit van de ambtenaren en bestuurders die de bestuurlijke aanpak vorm moeten geven buiten kijf staat. Is dat niet het geval, dan is de kans op ambtelijke en bestuurlijke corruptie levensgroot aanwezig.

Vanuit wetenschappelijk oogpunt bestaat er al met al genoeg reden om enige scepsis aan de dag te leggen voor evidence based policies. Sociaalwetenschappelijk onderzoek levert in de regel geen kant en klare, toepassingsgerichte kennis op, laat staan oplossingen voor complexe maatschappelijke problemen, zoals criminaliteit. Onderzoek speelt dan ook zelden een prominente rol bij concrete beslissingen. De invloed van evaluatieonderzoek - voor zover die al is vast te stellen - is meer een indirecte. Derden worden voorzien van inzichten en zienswijzen omtrent de totstandkoming,

25 Er even van uitgaand dat deze aanpak als best practice kan worden aangemerkt en, zoals eerder opgemerkt, is het prematuur om die kwalificatie nu al aan de bestuurlijke aanpak mee te geven. 
uitvoering en werking van beleid en het is van tal van omstandigheden - die buiten het bereik van de onderzoeker liggen - afhankelijk of die derden zich daaraan iets gelegen laten liggen. Ook onderzoek waaruit geen concrete aanwijzingen naar voren komen voor het bijstellen van het beleid of de uitvoering daarvan, kan zeer waardevolle wetenschappelijke kennis voortbrengen. Behalve aan kennisaccumulatie kunnen evaluaties bijvoorbeeld een bijdrage leveren aan het tot de juiste proporties terugbrengen van de beeldvorming op een bepaald terrein.

De hedendaagse criminoloog zou zich al met al niet zozeer moeten inspannen om 'het bewijs' panklaar op te dienen, maar zou veeleer als een moderne Theseus moeten proberen om stukje bij beetje een uitweg te vinden uit het doolhof aan bewijs. ${ }^{26}$ Zie daar de betekenis van de enigszins raadselachtige titel van deze oratie: de criminoloog baant zich met vallen en opstaan - waarbij het vallen overigens minstens zo belangrijk is als het opstaan - een weg door de evidence-maze. ${ }^{27}$ Succes daarbij is niet verzekerd: we zullen de uitgang van het labyrint vaker niet vinden dan wel, laat staan dat we in staat zullen zijn - of daartoe überhaupt de ambitie moeten hebben - om de Minotauros van deze tijd ${ }^{28}$ een beslissende slag toe te brengen. Verdwalen is niet erg, integendeel, dat is onlosmakelijk verbonden met de pijlers waarop wetenschapsbeoefening rust. Durfen creativiteit zijn in dat verband al genoemd, nieuwsgierigheid nog niet. Aan het laatste wil het mijns inziens nog wel eens ontbreken. Een groot gemis in het hedendaagse criminologisch onderzoek is dat vaak voorbijgegaan wordt aan de noden, wensen en behoeften van de mensen die onderwerp van onderzoek zijn. Onderzoekers, uitzonderingen daargelaten ${ }^{29}$, nemen op de hoogste

26 Om even het geheugen op te frissen: Theseus is een figuur uit de Griekse mythologie, een koningszoon uit Athene, die zich vrijwillig naar Kreta liet inschepen om daar de strijd aan te gaan met de Minotauros. Dit schepsel, met de kop van een stier en het lichaam van een mens, leefde in een labyrint en verscheurde jaarlijks zeven jongens en zeven meisjes die vanuit het aan Kreta onderworpen Athene aan hem werden geofferd. Theseus slaagde er niet alleen in de Minotauros te doden, maar ook om met behulp van Ariadne, de dochter van koning Minos, de uitgang van het labyrint te vinden. Hij bevestigde een van Ariadne gekregen draad aan de ingang van het labyrint en rolde deze draad uit terwijl hij zijn weg in het labyrint zocht.

27 Het Engelse woord maze heeft overigens niet alleen de betekenis van doolhof maar staat ook voor verbijstering. Het laatste ben ik, zoals de lezer inmiddels gemerkt heeft, over de starre, dogmatische opvatting dat de what-works benadering de hoogste vorm van wetenschapsbeoefening zou betreffen.

28 Criminaliteit wordt althans door menigeen als monster van deze tijd ervaren.

29 Tot die uitzonderingen reken ik bijvoorbeeld het recent verschenen proefschrift van Jan Dirk de Jong (2007), waarin de straatcultuur van jongeren in het Amsterdamse stadsdeel Overtoomse Veld indringend en beeldend wordt beschreven. 
ring van het theater plaats, besteden veel aandacht aan deskresearch, dossierstudie en/of ingewikkelde kwantitatieve analysemethoden, maar zijn onvoldoende in staat, dan wel bereid zich in de denk- en belevingswereld van de onderzoekspopulatie te verplaatsen. Gelukkig is een kentering waarneembaar, in die zin dat met de opkomst van de culturele criminologie enig tegenwicht wordt geboden aan het dominante 'what works'- paradigma. ${ }^{\circ}$ Ook bij het evalueren van de aanpak van serieuze vormen van criminaliteit kunnen we met de inzichten uit die stroming ons voordeel doen. Ik leg u zo uit op welke wijze. Eerst bespreek ik kort enkele specifieke problemen die zich bij dit type evaluaties voor kunnen doen.

\section{Evaluatie van preventieve maatregelen}

In een aantal recent afgesloten evaluatiestudies is de vraag opgeworpen hoe de effecten moeten worden gemeten van interventies die gericht zijn op het voorkomen van, dan wel indammen van de gevolgen van georganiseerde criminaliteit. Zowel in het proefschrift van Van der Schoot (2006) als de evaluatie van het Van Traa-project in Amsterdam (Huisman e.a., 2005) komt deze vraag prominent aan bod. In beide onderzoeken wordt een aantal redenen genoemd waarom het zo moeilijk is om inzicht te verkrijgen in de effecten van de geïntegreerde aanpak van georganiseerde criminaliteit. De eerste reden hangt samen met de (on)mogelijkheden om onderzoek te doen naar georganiseerde criminaliteit in het algemeen. Hoewel er over de reikwijdte van het begrip georganiseerde criminaliteit uiteenlopende opvattingen bestaan, zijn de meeste deskundigen het er wel over eens dat de bij georganiseerde criminaliteit betrokkenen hun daden, of in elk geval het illegale karakter hiervan, proberen te verbergen of te verhullen. Daarnaast valt uit de drie rapportages die tot dusverre zijn verschenen in het kader van de Monitor Georganiseerde Criminaliteit (Kleemans e.a., 1998; Kleemans e.a., 2002; Van de Bunt en Kleemans, 2007) af te leiden dat de in ons land aangetroffen vormen van georganiseerde criminaliteit zich vooral manifesteren op illegale markten (mensensmokkel, mensenhandel, drugproductie- en handel) en minder op legale markten. Door deze twee oorzaken is georganiseerde misdaad in Nederland een slecht zichtbare vorm van criminaliteit, waarvan de aard, laat staan de omvang, eenvoudig is vast te stellen.

30 Onder de noemer culturele criminologie wordt het criminologisch onderzoek geschaard waarin de culturele betekenis van criminaliteit en haar beheersing voorop staat. Cultuur moet in dat verband breed worden opgevat en slaat terug op processen van betekenisgeving en identiteit. 
Een extra complicerende factor bij het meten van effecten van preventieve maatregelen is dat het vrijwel onmogelijk is om te bepalen of als gevolg van deze maatregelen voorkomen is dat een als kwalijk aangeduid verschijnsel zich manifesteert of is gaan manifesteren. Hoe stel je onomstotelijk vast of iets er niet is doordat er drempels tegen zijn opgeworpen? Indien er al veranderingen in de georganiseerde criminaliteit kunnen worden vastgesteld, dan is nog steeds ongewis of deze verschuivingen wel aan de geïntegreerde aanpak kunnen worden toegeschreven.

Ondanks deze voetangels en klemmen zou het van weinig durf, creativiteit en nieuwsgierigheid getuigen om de stelling te betrekken dat over de impact van de geïntegreerde aanpak op de georganiseerde criminaliteit in het geheel geen wetenschappelijke verantwoorde uitspraken te doen zijn. Over de houdbaarheid van de veronderstellingen die aan een beleidsmaatregel of strategie ten grondslag liggen - in de literatuur veelal aangeduid als de programmatheorie of beleidstheorie - en de wijze waarop aan de maatregel of strategie in de praktijk wordt vormgegeven, zijn wel degelijk betrouwbare en valide uitspraken mogelijk. Ook kan een aantal concrete resultaten van de geleverde inspanningen inzichtelijk worden gemaakt, zoals het aantal ingetrokken vergunningen, aangekochte en opgeknapte panden etc, en kan worden geïnventariseerd hoe de diverse betrokkenen tegen de beleidsmaatregelen en de uitvoering daarvan aankijken. Wanneer zowel aan het begin als het einde van de evaluatieperiode bovendien een goede state of the art van de aard en ernst van de georganiseerde criminaliteit in de specifieke locale context voorhanden is, kan - om de door Rossi e.a. (1999) uitgezette lijn te volgen - getracht worden de aannemelijkheid vast te stellen van een correlatie tussen de vastgestelde veranderingen in het criminaliteitsbeeld en de voorgenomen en uitgevoerde beleidsmaatregelen.

\section{Programmatheorie}

Het blootleggen van de diverse assumpties die achter de te evalueren aanpak schuilgaan en het afzetten van deze veronderstellingen tegen bestaande wetenschappelijke bevindingen en inzichten, wordt doorgaans beschouwd als de eerste fase van het evaluatieproces. In de literatuur onder andere door Leeuw (2003) - wordt een aantal manieren beschreven waarop de onderzoeker deze eerste stap kan zetten. ${ }^{31}$ Bij het ontrafelen van

31 De meest frequent gevolgde lijn is die waarin de programmatheorie stapsgewijs, met behulp van documentanalyse en interviews met stakeholders en gebruikmakend van inzichten uit de argumentatieleer, wordt ontleed. Leeuw (2003) onderscheidt in dat verband zes stappen. 
de programmatheorie wordt een onderscheid gemaakt tussen normatieve, causale en finale assumpties (Leeuw, 1989; Nelen, 2000). Om dit onderscheid te verduidelijken en om te laten zien hoe een kritische beschouwing van beleidsassumpties er uit kan zien, geef ik van alledrie de typen een korte illustratie. Alle assumpties hebben betrekking op het Amsterdamse beleid om de problemen in de prostitutiesector in te dammen.

Normatieve assumpties weerspiegelen de morele fundering van een beleidsmaatregel. De casus Geerts, waarmee ik deze rede opende, bevat in dat opzicht een niet mis te verstane boodschap: de gemeente Amsterdam wenst geen zaken te doen met personen in de prostitutiebranche te wier aanzien het vermoeden bestaat dat zij zich schuldig maken aan malafide praktijken of wier bedrijfsvoering als ondoorzichtig wordt aangemerkt. Het probleem met deze assumptie is dat hierachter impliciet een andere veronderstelling schuil gaat, namelijk dat in de prostitutiesector het kaf moeiteloos van het koren kan worden gescheiden. De gedachte dat met het welslagen van het Project Emergo en het Coalitieproject 1012 uitsluitend nog bonafide exploitanten met een 'nette', transparante bedrijfsvoering in het Wallengebied overblijven, miskent echter zowel de aard van de ondernemers in de prostitutiesector als de geschreven en ongeschreven regels die al eeuwenlang in deze sector vigeren. Van oudsher oefent de seksindustrie aantrekkingskracht uit op 'vrijbuiters' die zich weinig gelegen laten liggen aan wettelijke beperkingen (zoals gedurende lange tijd het bordeelverbod) of aan morele afkeuring over hun handelen. De bedrijfscultuur die dat met zich heeft gebracht laat zich niet met een paar beleidsmaatregelen veranderen. Zelfs na de opheffing van het bordeelverbod in 2000 verkeert de sector in een morele schemerzone. Het runnen van een bordeel of een sekshuis wordt nog steeds niet als een 'normale' economische activiteit gezien, hetgeen een remmende werking heeft op 'bonafide' nieuwkomers met ondernemingszin. De bereidheid om zich in deze sector te nestelen wordt verder negatief beïnvloed door de terughoudendheid in de bancaire wereld om exploitanten van seksbedrijven van een lening te voorzien. De angst om geassocieerd te worden met vice en de reputatieschade die daarvan het gevolg kan zijn, heeft financiële instellingen er tot dusverre van weerhouden om financiële injecties aan de prostitutiesector te geven. Paradoxaal genoeg heeft deze opstelling er mede toe geleid dat exploitanten van bordelen en sekshuizen zijn aangewezen op irreguliere vormen van financiering, zoals de in de inleiding reeds genoemde informele bank van lening van Charles Geerts.

Bij causale assumpties wordt vanuit de veronderstelde oorzaken van een probleem doorgeredeneerd naar de mogelijke gevolgen van de aanpak 
ervan. Zoals hierboven al is toegelicht, behelst de geïntegreerde aanpak van georganiseerde criminaliteit dat maatregelen gericht op het bestrijden van criminaliteit worden gecombineerd met maatregelen als stadsvernieuwing, economische herstructurering, subsidiëring en straatmanagement. Aan deze aanpak ligt impliciet de assumptie ten grondslag dat verloederde buurten een voedingsbodem vormen voor georganiseerde criminaliteit en dat met het opknappen van die buurten hiertegen een drempel kan worden opgeworpen. Hoe plausibel deze veronderstelling op het eerste gezicht ook lijkt, empirische ondersteuning voor de houdbaarheid er van is er niet. In het al genoemde rapport van Huisman e.a. (2005) over de evaluatie van het Van Traa-project wordt vastgesteld wordt dat er weliswaar voldoende empirisch bewijs voorhanden is dat georganiseerde criminaliteit een negatieve uitwerking heeft op de leefbaarheid in buurten, maar dat deze relatie niet zomaar kan worden omgedraaid. Uit oogpunt van georganiseerde misdaadpreventie is het dan ook niet op voorhand aangewezen om aan de verbetering te werken van de leefbaarheid van een buurt.

Finale assumpties ten slotte hebben betrekking op de relaties tussen de nagestreefde doelen en de daartoe beschikbare middelen. De casus Geerts markeert een belangrijke ommezwaai in het denken over de meest geschikte aanpak van serieuze vormen van criminaliteit. Het is een publiek geheim dat de gemeente Amsterdam jarenlang met Charles Geerts heeft onderhandeld over de locaties waar hij zijn nering kon drijven. Toegegeven, de gemeente kon de vergunningen van de betrokkene toen nog niet met een beroep op de wet BIBOB intrekken, dan wel een verlenging weigeren. De wet BIBOB is namelijk pas sinds medio 2003 van kracht. Ondanks deze wettelijke beperking moeten de onderhandelingen met Geerts in een breder perspectief worden geplaatst. Het feit dat de gemeente ook jarenlang door middel van een vaste liaison in gesprek bleef met een gezelschap dat het OM liever vandaag nog dan morgen tot verboden organisatie zou willen verklaren - ik doel hier uiteraard op het Amsterdamse chapter van de Hells Angels - geeft aan dat de beleidsverantwoordelijken op het stadhuis lange tijd de overtuiging waren toegedaan dat het de voorkeur verdiende om op bepaalde relevante knooppunten contacten met sleutelfiguren te onderhouden in plaats van deze (groepen van) personen publiekelijk in de ban te doen.Een dergelijk streven paste in het gedoogbeleid dat de afgelopen decennia op tal van probleemvelden (drugs, prostitutie, gokken etc) werd toegepast. Onder invloed van diverse omstandigheden - zoals uitvoerig beschreven door onder andere Van Swaaningen (2005) - is de gedoogcultuur in Nederland echter in een betrekkelijk kort tijdsbestek ingeruild voor een stringenter crime control-beleid. Deze veranderingen hebben ook 
hun weerslag gehad op de finale assumpties in de programmatheorie van de Amsterdamse aanpak van georganiseerde criminaliteit. Ook op dit vlak is - om met Jock Young (1999) te spreken - een kentering waarneembaar van een 'inclusive' naar een 'exclusive' society.

Uiteraard bestaat de programmatheorie achter de geïntegreerde aanpak uit meer assumpties dan het hierboven genoemde drietal en valt er over elk van die drie veronderstellingen ook beduidend meer te vertellen dan ik nu in een kort tijdsbestek heb gedaan. Niettemin hoop ik met de drie voorbeelden duidelijk gemaakt te hebben dat een kritische beschouwing van de programmatheorie het draai- en angelpunt vormt van het evaluatieproces. Niet alleen aan het begin van dat proces om de veronderstellingen achter het beleid bloot te leggen, maar ook aan het einde wanneer de vraag aan de orde komt hoe aannemelijk het is om de vastgestelde veranderingen te relateren aan het gevoerde beleid. Zoals ik eerder heb benadrukt, hoort daarbij niet de vraag òf iets werkt centraal te staan, maar veeleer de vragen waarom een interventie zou kunnen werken, voor wie, en onder welke omstandigheden?

De laatste twee vragen onderstrepen de noodzaak om voldoende inzicht te verwerven in het te bestrijden probleem, de maatschappelijke context waarin dat zich manifesteert en, last but not least, in de betekenis die personen op wie de interventie direct of indirect is gericht, aan hun eigen gedrag, de ontwikkelingen in de branche en aan de reactie van overheidszijde hechten. Zie daar de toegevoegde waarde van de culturele criminologie voor het evaluatieonderzoek. Meer dan nu het geval is, zal in evaluatieonderzoek het perspectief van de doelgroep moeten worden omarmd en zal om op een meer "verstehende" wijze informatie moeten worden verzameld. Er zullen met andere woorden serieuze pogingen moeten worden ondernomen om de gewoontes, culturele percepties en interpretaties van de subjecten die met de interventie te maken krijgen, te doorgronden en te begrijpen. Om het voorbeeld van de geïntegreerde aanpak van georganiseerde criminaliteit er weer even bij te nemen: bij een toekomstige evaluatie van de maatregelen die in het kader van deze aanpak worden genomen, horen ook diepte-interviews met sleutelpersonen in een bepaalde sector of een bepaald gebied, observaties en andere stadsetnografische methoden. De langs andere wegen verkregen onderzoeksgegevens krijgen daarmee meer diepgang en reliëf. Of het nu gaat om de drijfveren van betrokkenen, de legale en illegale gelegenheidsstructuren, de verweving tussen criminele en reguliere economische activiteiten, de interactie tussen malafide praktijken en de overheidsreactie daarop, op al deze facetten wordt meer licht geworpen wanneer de sociale werkelijkheid ook van binnenuit wordt bestudeerd en beschreven. 
Toegegeven, er is in het Nederlandse taalgebied al een aantal studies te noemen waarin de invloed van de culturele criminologie merkbaar is. ${ }^{32}$ In evaluatieonderzoek is deze invloed echter tot dusverre beperkt gebleven. De evaluatie van het Van Traa-project (Huisman e.a., 2005) bevatte weliswaar een apart deelonderzoek waarin 26 ondernemers in het Wallengebied uitgebreid werden geïnterviewd over allerhande aspecten van de bestuurlijke aanpak en de gevolgen daarvan voor hun bedrijfsvoering, maar in het hoofdrapport van de evaluatie is van de bevindingen uit dat onderzoek slechts spaarzaam gebruik gemaakt.33 In toekomstige studies zullen dergelijke mogelijkheden tot verdieping beter moeten worden benut.

\section{Procesevaluatie}

Ook bij de evaluatie van de wijze waarop in de praktijk aan beleidsmaatregelen vorm wordt gegeven zouden onderzoekers inspiratie kunnen putten uit de culturele criminologie. In de wetenschap dat vele beleidsvoornemens van bovenaf op de uitvoerende medewerkers worden 'geparachuteerd' is het zaak om te achterhalen hoe de laatsten het beleid interpreteren en waarderen en welk belang zij toekennen aan de handhaving daarvan. Het vaststellen van belangen, behoeften en prioriteiten in de sfeer van de beleidsuitvoering veronderstelt dat de onderzoeker de uitvoering van nabij volgt, zich verdiept in de organisatiestructuur, maar vooral -cultuur van de betrokken instanties en zich ook kan verplaatsen in de dilemma's waarmee de uitvoerders geconfronteerd worden. Ook voor dit deel van het evaluatietraject geldt: met deskresearch en gestandaardiseerde vragenlijsten kom je er niet.

Procesevaluaties worden in mijn ogen ondergewaardeerd. De heersende gedachte onder deskundigen is, om met Leeuw (2005) te spreken, "dat vele inspanningen die onder de noemer van evaluatie worden verricht, het niveau van een procesevaluatie nauwelijks overstijgen." De laatste (dis) kwalificatie suggereert - wat mij betreft ten onrechte - dat ook ten aan-

32 Denk bijvoorbeeld aan het rapport van Bovenkerk e.a. (2004) over het fenomeen loverboys. Ook in het onderzoek van Biesma e.a. (2006) naar illegale vormen van prostitutie - een deelrapport van de overkoepelende evaluatie van de gevolgen van de opheffing van het bordeelverbod (Daalder, 2007) is geprobeerd om door middel van een groot aantal interviews en observaties meer zicht te krijgen op irreguliere vormen van prostitutie.

33 Beschouw deze kritische kanttekening als een vorm van zelfreflectie. Ik ben namelijk coauteur van het genoemde evaluatierapport. De overige auteurs delen overigens mijn mening dat er meer uit het veldonderzoek in het Wallengebied te halen was geweest. 
zien van verschillende typen evaluatie een hiërarchie denkbaar is en dat procesevaluaties daarbij niet hoog scoren. Hoewel wordt onderkend dat procesevaluaties inzicht kunnen verschaffen in de dynamiek van de implementatie en handhaving van beleid, zouden zij betrekkelijk weinig kennis genereren over de precieze werking van die programma's.

Uiteraard is een procesevaluatie alleen niet voldoende om uitspraken te doen over de vraag onder welke condities een bepaald programma voor een bepaalde doelgroep bepaalde resultaten zou kunnen opleveren. Daartoe zullen, het is hierboven al toegelicht, aanvullende onderzoeksinspanningen moeten worden verricht. Wat echter bij de beoordeling van procesevaluaties over het hoofd wordt gezien, is dat deze, mits zij daarop zijn ingericht, inzicht kunnen bieden in één van de meest onderbelichte aspecten van de rechtshandhaving: de executie van sancties en maatregelen. Acht jaar geleden karakteriseerde Van de Bunt (2000) de tenuitvoerlegging van sancties als het 'stiefkindje' van de strafrechtspleging. Naar mijn overtuiging heeft die vaststelling aan actualiteitswaarde niets ingeboet, sterker nog, heeft zij niet alleen onverkort betrekking op de strafrechtspleging, maar op de rechtshandhaving in brede zin. Het is eigenlijk moeilijk te bevatten dat slechts weinigen, inclusief wetenschappers die belast zijn met een evaluatieopdracht, zich de vraag stellen of de in het kader van een interventie opgelegde straffen en maatregelen eigenlijk wel (geheel) ten uitvoer worden gelegd, laat staan dat zij zich bekreunen om de vraag of de uitvoering geschiedt in overeenstemming met de intenties van de strafoplegger. Stilzwijgend wordt bij beide vragen van een bevestigend antwoord uitgegaan.

Toch is de tenuitvoerlegging van sancties en maatregelen geen vanzelfsprekendheid. 34

In de WODC/CBS publicatie "Criminaliteit en Rechtshandhaving 2006" stuitte ik op de volgende intrigerende passage in relatie tot het uitzitten van een gevangenisstraf: "de eenvoudigste en meest voorkomende manier om zich aan detentie te onttrekken is het zich niet melden bij de inrichting nadat men hiertoe werd opgeroepen" (Van der Heide en Eggen, 2007, p. 189). De passage verwijst naar de praktijk rondom de categorie lopende vonnissen - ofwel de gerechtelijke uitspraken waarbij de veroordeelde

34 Ik sluit niet uit dat we enigszins verbaasd op zullen kijken wanneer de resultaten bekend worden van een onderzoek waarin at random een - voor statistische doeleinden voldoende aantal interventies, sancties of maatregelen bij de kop wordt genomen en systematisch wordt nagegaan of en hoe de tenuitvoerlegging van die interventies heeft plaatsgevonden. Het is eigenlijk moeilijk te bevatten dat een dergelijk onderzoek nog nooit heeft plaatsgevonden. 
ten tijde van de uitspraak niet in voorlopige hechtenis zit en thuis moet wachten op een oproep van het Centraal Justitieel Incasso Bureau (CJIB) om zich bij een penitentiaire inrichting te melden. Opvallend genoeg worden bij deze constatering geen aantallen genoemd en valt uit het rapport niet op te maken hoeveel mensen op jaarbasis een oproep naast zich neerleggen, welke inspanningen politie en justitie vervolgens moeten leveren om de betrokkenen aan te houden en hoeveel tijd verstrijkt tussen het moment van de onherroepelijke uitspraak en die eventuele aanhouding. ${ }^{35}$ De meeste gedetineerden die zich op enigerlei wijze aan detentie hebben onttrokken, worden evenwel, zo stelt het rapport ons gerust, "vroeg of laat" weer gearresteerd. (Van der Heide en Eggen, 2007, p. 189).

Ondanks deze omfloerste formulering lijken we ons wat de executie van vrijheidsstraffen dus geen grote zorgen te hoeven maken. Ten aanzien van bepaalde vermogenssancties en maatregelen ligt de situatie echter anders en is de vraag gerechtvaardigd welk deel van de opgelegde betalingsverplichting eigenlijk daadwerkelijk wordt geïncasseerd. Van strafrechtelijke ontnemingsmaatregelen is bijvoorbeeld al sinds jaar en dag bekend dat de executie bijzonder moeizaam verloopt, niet alleen qua tijd die het ontnemingsproces in beslag neemt maar, zeker zo belangrijk, ook qua uiteindelijke opbrengst (Faber en van Nunen, 2002)..$^{36}$ Ook in fiscalibus is de situatie niet ongewoon dat er een ernstige kloof gaapt tussen het bedrag van de belastingaanslag en het bedrag dat uiteindelijk kan worden geïncasseerd. Over de tenuitvoerlegging van bestuursrechtelijke maatregelen, zoals de invordering van een dwangsom of een bestuurlijke boete, weten we eigenlijk bitter weinig, maar het is niet aannemelijk dat de executieproblemen die zich in het strafrecht en het belastingrecht voordoen, zich in de bestuursrechtelijke sfeer niet zouden manifesteren.

Het probleem voor wetenschappelijke onderzoekers is dat de informatie die benodigd is om te kunnen achterhalen of er in specifieke gevallen überhaupt een tenuitvoerlegging van bepaalde sancties en maatregelen heeft plaatsgevonden, niet altijd beschikbaar, dan wel toegankelijk is. Toch

35 In de in de bijlage van het rapport Criminaliteit en Rechtshandhaving opgenomen tabel 6.7 worden uitsluitend cijfers weergegeven van mensen die niet zijn teruggekeerd van weekendverlof en die zijn ontvlucht. Tevens worden aantallen genoemd van aangehouden gedetineerden die zich aan detentie hebben onttrokken.

${ }_{36}$ In het rapport Criminaliteit en Rechtshandhaving 2006 worden de problemen rond de executie van ontnemingsmaatregelen nog eens bevestigd. De werkvoorraden bij het CJIB nemen almaar toe. Opvallend genoeg worden geen bedragen genoemd in relatie tot geïncasseerde betalingsverplichtingen 
is dit slechts een deel van het probleem. Onderzoekers lijken, ik stelde het al hierboven, ook niet bijster geïnteresseerd te zijn in het executievraagstuk en stellen zelden alles in het werk om de voor evaluatiedoeleinden toch zeer wezenlijke informatie boven tafel te krijgen. Het feit dat in een niet gering aantal evaluatiestudies wordt volstaan met het genereren van een overzicht van de getroffen maatregelen, zonder dat wordt geverifieerd of deze ook ten uitvoer zijn gelegd, spreekt wat dat betreft boekdelen.

Om te laten zien hoe belangrijk gegevens over de tenuitvoerlegging van maatregelen zijn voor de beoordeling van de werking van een beleidsprogramma keer ik nog eenmaal terug naar het voorbeeld van de geïntegreerde aanpak van georganiseerde criminaliteit. In de al vaker aangehaalde evaluatie van het Van Traa-project wordt onder de noemer 'geboekte resultaten' een aantal maatregelen genoemd die - in strafrechtelijke, fiscale en/ of bestuurlijke zin zijn getroffen (Huisman e.a., 2005). Opmerkelijk genoeg geeft het rapport geen uitsluitsel over de vraag in hoeverre de door de belastingdienst opgelegde aanslagen en naheffingen ook zijn ingevorderd en wordt evenmin duidelijk in hoeverre de aangekondigde intrekking van een aantal vergunningen ook daadwerkelijk is geëffectueerd. 37

Achteraf bezien is het eenvoudig om te wijzen op zaken die in evaluatiestudies verzuimd of over het hoofd gezien zijn. De reden dat ik deze omissies hier heb behandeld is niet om de kwaliteit van deze studies ex-post nog eens ter discussie te stellen, maar veeleer om te wijzen op de kansen en mogelijkheden die we tot dusverre in evaluatieonderzoek onvoldoende hebben benut. Evaluatie van criminaliteitsbeleid, zoveel hoop ik u duidelijk te hebben gemaakt, is een intrigerende maar ook gecompliceerde aange-

37 Zoals de casus Geerts laat zien, wil het nog wel eens voorkomen dat door de benadeelde alle rechtsmiddelen worden aangegrepen die het bestuursrecht biedt om een beschikking van een lagere overheid aan te vechten. De uitkomsten van dit type procedures worden niet systematisch meegenomen in evaluatieonderzoek. Een probleem daarbij is dat de administratieve procedures bijzonder tijdrovend kunnen zijn en de evaluatietermijn overschrijden. Evenmin wordt voldoende rekening gehouden met de mogelijkheid dat de aangekondigde bestuurlijke maatregel leidt tot overleg tussen de lagere overheid en de benadeelde, als gevolg waarvan de maatregel wordt opgeschort of zelfs wordt ingetrokken. Deze gang van zaken weerspiegelt de belangenconstellatie in een gebied of sector. In het onderzoek van Huisman e.a. (2005) wordt dienaangaande vastgesteld dat de gemeente weliswaar beschikt over een pressiemiddel in de vorm van het vergunningenstelsel, maar dat ondernemers eveneens een machtsmiddel in handen hebben, namelijk het bezit van onroerend goed. De grotere ondernemers en de gemeente zijn in economische zin min of meer op elkaar aangewezen: ze zijn 'gedwongen' met elkaar te overleggen, willen ze hun eigen belang met enig succes kunnen nastreven. 
legenheid, zeker wanneer dat beleid gericht is op de preventie van slecht zichtbare vormen van criminaliteit en het wegnemen van gelegenheidsstructuren. Evaluatie behelst meer dan de instrumentele vraag of iets werkt of niet, maar dient er op gericht te zijn om de ratio achter- en de dynamiek en mechanismen van hedendaagse criminaliteitsbestrijding bloot te leggen. En hoewel ik er in deze rede niet expliciet bij stil heb gestaan, moet er in een evaluatie natuurlijk ook aandacht worden besteed aan de mate waarin beleidsmaatregelen op gespannen voet staan met elementaire rechtsbeginselen. Het opzetten en uitvoeren van een evaluatiestudie is al met al een uitdagende klus waarin wetenschappelijke inbreng vanuit verschillende disciplines mogelijk en gewenst is.

\section{Onderzoeksprogramma}

Dames en heren, het moge duidelijk zijn: de komende jaren kunt $u$ de nodige evaluatiestudies op het terrein van de criminele politiek vanuit onze afdeling strafrecht en criminologie verwachten. Die evaluatieonderzoeken zullen niet worden uitgevoerd op basis van starre, dogmatische principes, maar vanuit een kritische, wetenschappelijke houding waarin ruimte is voor durf, creativiteit en nieuwsgierigheid en waarin de uitvoering van interventies en het perspectief van degenen die aan die interventies worden onderworpen voldoende aan bod komen. Bij de uitvoering van die studies zullen we allianties smeden binnen en buiten de faculteit. Binnen de faculteit zullen de banden worden aangehaald met de collega's van publiekrecht - bij studies naar de werking van de bestuurlijke aanpak van criminaliteit een vanzelfsprekende partner - privaatrecht - denk b.v. aan evaluaties van de aanpak van misbruik van rechtspersonen en, als we de grenzen overgaan, internationaal recht. Maar laten we vooral ook niet de collega's van Metajuridica vergeten. Binnen die capaciteitsgroep is Frans Leeuw, toch een van de toonaangevende deskundigen op het gebied van de beleidsevaluatie, een belangrijke bondgenoot. Daarnaast ligt samenwerking voor de hand met de rechtspsychologen, in het bijzonder bij de evaluatie van rechercheprocessen, een terrein dat van oudsher mijn grote interesse heeft.

Buiten de muren van de faculteit zijn de psychologen onder leiding van Harald Merckelbach voor ons aantrekkelijke partners. We mogen misschien van mening verschillen in hoeverre evidence based science al dan niet het leidende principe van wetenschapsbeoefening moet zijn, we zijn het eens over de toegevoegde waarde van een multidisciplinaire benadering. Mijn credo is dan ook: laat alle bloemen bloeien en laten we proberen elkaar te 
versterken in plaats van te verketteren. Zeker op het terrein van evaluatieonderzoek.

Uiteraard wordt in het criminologische onderzoek niet alleen het vizier gericht op de evaluatie van justitiële en buitenjustitiële interventies, maar wordt ook aandacht besteed aan de aard, ernst, omvang en ontwikkeling van bepaalde vormen van criminaliteit. Voortbordurend op de door mijn gewaardeerde voorganger Grat van den Heuvel binnen de UM ontwikkelde traditie om onderzoek te doen naar allerhande vormen van organisatiecriminaliteit zal het accent daarbij worden gelegd op de financiële facetten van criminaliteit. Het onderzoek zal zich bewegen op het grensvlak van georganiseerde criminaliteit en organisatiecriminaliteit, waarbij onder meer gedacht kan worden aan het entameren van (internationale) studies naar fraude, corruptie en witwassen. In de sfeer van het laatstgenoemde onderzoeksveld valt te denken aan een verdieping van het onderzoek naar malafide praktijken in de vastgoedsector. ${ }^{38}$ Daarbij kunnen de handen ineen worden geslagen met de ook aan de UM werkzame hoogleraar vastgoedkunde Piet Eichholtz. Hoewel bij criminele activiteiten in de vastgoedsector lange tijd het vizier eenzijdig gericht was op het netwerk rondom een aantal beruchte Willem's, heeft het recente grootschalige justitiële onderzoek naar een aantal leidinggevenden van toonaangevende institutionele beleggingsfondsen duidelijk gemaakt dat fraude en corruptie van beleggers van naam vermoedelijk meer schade berokkenen dan drugshandelaren die hun wederrechtelijk verkregen voordeel in de vastgoedsector willen investeren. Bij onderzoek naar de aard en omvang van criminaliteit in deze sector - maar eigenlijk geldt dat voor het fraude- en witwasonderzoek in het algemeen - moeten we dan ook definitief af van het gekunstelde onderscheid onderwereld-bovenwereld.

Natuurlijk zullen we bij onze onderzoeksactiviteiten ook met andere Nederlandse universiteiten en onderzoeksinstituten (blijven of gaan) samenwerken. Daarnaast nodigen de geografische ligging van Maastricht, de Europese ambities van de faculteit, alsmede de toenemende internationalisering van de hedendaagse criminologiebeoefening uit tot het entameren van grensoverschrijdende projecten en activiteiten. Met enkele naburige Belgische en Duitse universiteiten zijn in dat verband de contacten al gelegd. Maar ook met andere Europese en niet-Europese partners zullen samenwerkingsverbanden worden gesmeed, dan wel geïntensiveerd.

${ }^{8}$ Ferwerda e.a. (2007) hebben een verkennend onderzoek verricht naar malafide praktijken op de woningmarkt. Vanuit het WODC is hieraan een vervolg gegeven. Het onderzoeksrapport van dat onderzoek wordt in 2008 verwacht. Hetzelfde geldt voor de studie die ik samen met enkele VU-collega's in opdracht van de Rijksgebouwendienst heb verricht naar onregelmatigheden op de kantorenmarkt. 


\section{Dankwoord}

Dames en heren, ik sluit deze rede af, maar niet voordat ik een kort dankwoord heb kunnen uitspreken.

Leden van het College van Bestuur en van het bestuur van de faculteit der rechtsgeleerdheid van de Universiteit Maastricht. Het feit dat u een algemene leerstoel voor de criminologie in het leven heeft geroepen, onderstreept dat $u$ meer aandacht voor criminologische vraagstukken in het onderwijs en onderzoek van de Universiteit Maastricht wenselijk acht. Ik ben u dankbaar dat u mij in de gelegenheid hebt gesteld om deze opdracht te vervullen en verder uit te werken. Collega André Klip wil ik ook in deze dankbetuiging betrekken, omdat ik weet dat hij zich zowel voor de leerstoel als mijn komst sterk heeft gemaakt.

Collega's van de capaciteitsgroep strafrecht en criminologie. In een jaar tijd zijn jullie mij bijzonder dierbaar geworden. Hoewel juristen en criminologen niet altijd dezelfde taal spreken en mijn denkrichting minder gestoeld is op elementaire rechtsbeginselen dan jullie benadering van de sociale werkelijkheid, voel ik me temidden van jullie meer dan thuis. Ik voorzie ook allerlei mooie gemeenschappelijke projecten, omdat juist bij het uitvoeren van beleidsevaluaties en wetsevaluaties een sociaal-wetenschappelijk en juridische benadering hand in hand gaan.

Het doet mij goed om hier vandaag ook een groot aantal ex-collega's en mensen uit mijn door de jaren heen opgebouwde relatienetwerk te zien. Zowel op mijn dienstverband bij het WODC als dat aan de VU kijk ik met veel plezier en voldoening terug. Mijn adagium was en is dat de zingeving en bevrediging van werk niet uitsluitend bepaald worden door de intellectuele uitdaging en diepgang van de klussen waarvoor ik me gesteld zie, maar - minstens zo belangrijk - door de mensen met wie die klussen worden geklaard. Collega's en werkrelaties zijn belangrijk als bron voor inspiratie, reflectie en, last but not least, zelfrelativering en humor. Op alle fronten ben ik door de jaren heen bijzonder goed aan mijn trekken gekomen.

Beste studenten, geloof het of niet, maar het verzorgen van onderwijs is een van de leukste en inspirerendste taken van een baan aan een universiteit. En hoewel mijn ervaring aan de UM nog beperkt is, ben ik naar mijn gevoel met de neus in de boter gevallen. Of het probleem gestuurd onderwijs een bijdrage heeft geleverd aan jullie gedrevenheid en enthousiasme, laat ik maar even in het midden. Ook dat behoort tot de evidence maze. Feit is dat jullie bevlogenheid aanstekelijk werkt en dat ik een mooie toekomst voorzie voor de plaats van criminologie in diverse curricula van deze faculteit en ook daarbuiten. Laten we proberen elkaar bij de les te houden en zowel qua 
inhoud als vorm het criminologieonderwijs van nieuwe en verfrissende ideeën en inzichten te voorzien. En we hoeven daarbij echt niet uitsluitend te putten uit de klassieke criminologische literatuur en onderwijsvormen, maar kunnen ons ook laven aan allerhande culturele inspiratiebronnen van deze tijd - variërend van weblogs, documentaires, films, romans, gastlezingen, seminars en noem het allemaal maar op.

Lieve vrienden en vriendinnen, de meesten van jullie komen van ver. Het feit dat een groot aantal van jullie een halve werkdag heeft opgeofferd en de vrijdagmiddagfile heeft getrotseerd om bij deze gelegenheid aanwezig te zijn, doet mij goed. Het voelt bijna als een reünie. Ook ben ik blij de gezichten te zien van onze nieuwe vrienden uit Maastricht. We wonen hier pas een half jaar, maar mede dankzij jullie verloopt het acclimatiseringproces heel soepel.

Lieve schoonfamilie, familie, lieve pa en ma. Ik vind het geweldig dat ik deze plechtigheid in jullie aanwezigheid kan beleven. Naast onze vorige week overleden vriendin Alice ontbreekt Elzo op het appèl, maar beiden zijn in mijn gedachten hier wel present. Elzo had deze bijeenkomst en de ambiance er omheen zonder twijfel - om een van zijn eigen stopwoordjes te gebruiken - fantástisch gevonden.

$\mathrm{Pa}$, ik heb, zoals je gehoord hebt, ook enkele paradoxen ten tonele gevoerd, maar die halen het niet bij de statische paradoxen uit jouw meesterwerk. Mijn wetenschappelijke nieuwsgierigheid heb ik van geen vreemde.

Mam, voor jou heeft mijn aanstelling in Zuid-Limburg misschien wel de meeste emotionele waarde. We zijn tenslotte in de regio neergestreken waar jouw wortels liggen. Mijn gedachten gaan terug naar de tijd waarin de drie gebroeders Nelen zich in Nuth samen met zus Marlou schoorvoetend begaven in de richting van een plaats delict. Hoewel ouders, opa en oma, ooms en tantes en andere significant others niet nalieten ons te waarschuwen voor de vermeende gevaren die samenhingen met een tocht naar een kuil in de achtertuin van het huis van onze grootouders - door ons inmiddels omgedoopt tot "het ravijn" - sloegen wij steevast alle raadgevingen in de wind en togen naar de plek waar, zo wilde de overlevering, een vrouw na een crime passionelle de dood had gevonden en begraven was. Verbijsterd stonden we aan de rand van de kuil en fantaseerden met elkaar over hoe dit gruwelijke scenario zich voltrokken had. Misschien is daar toen wel de kiem gelegd voor mijn latere carrière in de criminologie. Hoe dan ook, de belangstelling voor criminaliteit en de bestrijding daarvan was er al op jonge leeftijd.

Lieve Bente, lieve Charlotte. Ik zal er geen doekjes om winden. Ja, het is mijn schuld dat jullie werden weggerukt uit je vertrouwde omgeving in 
Amsterdam. Hoewel jullie behoorlijk opzagen tegen de verhuizing en de veranderingen in jullie leven, hebben jullie je dapper door de eerste periode heengeslagen. Inmiddels zijn jullie al zo goed geacclimatiseerd, dat ik jullie hier vermoedelijk met geen tien paarden meer wegkrijg. Hoe zie ik er trouwens uit in mijn lange jurk? Jullie hebben me al een keer hartelijk uitgelachen en vergeleken met een pastoor, maar ook hieraan raken jullie ongetwijfeld gewend.

Lieve Kit, de laatste woorden zijn natuurlijk voor jou. Jij bent de dapperste van ons tweeën. Want waar ik de neiging vertoon me vast te klampen aan de vertrouwde zaken en zekerheden in het leven, durf jij ook dingen los te laten en het onbekende met nieuwsgierigheid en vertrouwen tegemoet te treden. Met jou aan mijn zijde durf ik elk doolhof in.

Ik heb gezegd. 


\section{Literatuur}

Biesma, S., R. van der Stoep, H. Naayer, B. Bieleman e.a. (2006), Verboden bordelen; evaluatie opheffing bordeelverbod, deelproject 3: niet legale prostitutie, Groningen: Intraval.

Bijleveld, C.C.J.H. (2003), Mens durf te meten!; over methoden en technieken van criminologisch onderzoek, Den Haag, Boom Juridische uitgevers (oratie VUA, 8 maart 2002).

Borgers, M.J. (2007), De vlucht naar voren, Den Haag: Boom Juridische uitgevers (oratie VUA, 16 maart 2007).

Bovenkerk, F., M. van San, M. Boone, T. Boekhout van Solinge, D. J. Korf (2004), 'Loverboys' of modern pooierschap in Amsterdam, Utrecht, Willem Pompe Instituut voor Strafrechtswetenschappen.

Bunt, H.G. van de (2000), Aan het eind van de keten; de strafexecutie stiefmoederlijk bedeeld, Justitiële verkenningen, jrg. 26, nr. 4, pp. 10-18.

Bunt, H.G. van de (2007), Problemen van transparantie en controleerbaarheid in criminologisch onderzoek. In: Soeteman A., F. Van den Born (red.), Ethiek van empirisch sociaal-wetenschappelijk onderzoek, Amsterdam: Koninklijke Nederlandse Akademie van Wetenschappen (KNAW), pp. 27-34.

Bunt, H.G. van de, E. Kleemans (2007), Georganiseerde criminaliteit in Nederland: Derde rapportage op basis van de WODC-monitor, Den Haag: WODC.

Daalder, A.L. (2007), Prostitutie in Nederland na opheffing van het bordeelverbod, Den Haag: Boom Juridische uitgevers, WODC, Onderzoek en Beleid nr. 249.

Dieren, W. van.(2007), Marktideologische spin ondergraaft wetenschappelijke fundering van beleid. In: Soeteman A., F. Van den Born (red.), Ethiek van empirisch sociaal-wetenschappelijk onderzoek, Amsterdam: Koninklijke Nederlandse Akademie van Wetenschappen (KNAW), pp. 71-76.

Donahue, J.J., III, S.D. Levitt (2001), The impact of legalized abortion on crime, Quarterly Journal of Economics, 116 (2), pp. 379-420.

Engbersen, G. (2007), De verhouding tussen wetenschap en beleid. Over wittebroodsweken en LAT-relaties. In: Soeteman A., F. Van den Born (red.), Ethiek van empirisch sociaal-wetenschappelijk onderzoek, Amsterdam: Koninklijke Nederlandse Akademie van Wetenschappen (KNAW), pp. 63-70.

Faber, W., A. van Nunen (2002), Het ei van Columbo?: evaluatie van het project financieel rechercheren, Oss: Faber organisatievernieuwing. 
Ferwerda, H., Staring, R., Vries Robbé, E, de., Bunt, J., van de. (2007), Malafide activiteiten in de vastgoedsector. Een exploratief onderzoek naar aard, actoren en aanpak. Amsterdam: SWP.

Garland, D. (2001), The culture of control; crime and social order in contemporary society, Oxford: Oxford Press.

Heide, W. van der, A.Th.J. Eggen (red.) (2007), Criminaliteit en rechtshandhaving 2006, WODC/CBS, Boom Juridische uitgevers.

Huisman, W., M. Huikeshoven, H. Nelen, H. van de Bunt, J. Struiksma, (2005), Het Van Traa-project: Evaluatie van de bestuurlijke aanpak van georganiseerde criminaliteit in Amsterdam, Den Haag: Boom Juridische uitgevers.

Kleemans, E.R., E.A.I.M. van den Berg, H.G. van de Bunt (1998), Georganiseerde criminaliteit in Nederland. Rapportage op basis van de WODC-monitor, Den Haag: WODC.

Kleemans, E.R., Brienen, M.E.I. \& Bunt, H.G. van de (2002). Georganiseerde criminaliteit in Nederland: Tweede rapportage op basis van de WODC-monitor, Den Haag: WODC.

Kleemans, E., C Klein Haarhuis, F. Leeuw, M. van Ooyen-Houben (2007), Law enforcement interventions in the Netherlands: mapping interventions and 'browsing' for evidence, Evidence \& Policy, vol. 3, no. 4, pp. 487-504.

Köbben A.J.F. , H.Tromp (1999), De onwelkome boodschap; of hoe de vrijheid van wetenschap bedreigd wordt, Amsterdam: Jan Mets.

Leeuw, F.L. (1989), Beleidstheorieën; veronderstellingen achter beleid. In A. Hoogerwerf (red.), Overheidsbeleid, Alphen aan den Rijn: Samsom.

Leeuw, F.L. (2003), Reconstructing program theories: methods available and problems to be solved, American Journal of Evaluation, vol. 24, no. 1, pp 5-20.

Leeuw, F.L. (2005), (Quasi-)Experimental evaluations and Dutch society; introductory conference remarks, WODC, 4 november 2005.

Majone, G. (1989), Evidence, Argument and Persuasion in the Policy Process, New Haven, CT: Yale University Press.

Nelen, J.M.. (2000), Gelet op de Wet, de evaluatie van strafwetgeving onder de loep, Amsterdam: Vrije Universiteit Amsterdam, 2000.

Pawson, R. (2006), Evidence-based Policy; a realist perspective, London: Sage Publications. 
Rovers, B. (2007), Ze deugen nergens voor: het Belief-effect in justitiële jeugdinterventies, lectorale rede Avans Hogeschool, 9 november 2007.

Rossi, P.H., Freeman, H.E. \& Lipsey, M.W. (1999). Evaluation: A systematic approach, Thousand Oaks: Sage Publications.

Ruiter, C. de (2007), Ik heb niets beters te doen, Maastricht, Universiteit Maastricht (oratie UM, 28 september 2007).

Schoot, C.R.A. van der (2006), Organized Crime prevention in the Netherlands. Exposing the Effectiveness of Preventive Measures, Den Haag: Boom Juridische uitgevers.

Swaaningen, R. van (2005), Public Safety and the management of fear, Theoretical Criminology, vol. 9, no. 3, pp. 289-305.

Young, J. (1999), The Exclusive Society; social exclusion, crime and difference in late modernity, London: Sage.

Zimring, F.E. (2007), The Great American Crime Decline, Oxford, New York: Oxford University Press. 